\title{
„Hely” és identitás. Egy temerini középiskolások körében végzett vizsgálat tanulságai
}

\section{"Locality" and identity. Lessons of a research conducted among secondary school students in Temerin}

\author{
DUŠAN RISTIĆ, NAGY IMRE, SAŠA KICOŠEV
}

\begin{abstract}
Bevezető
2012 áprilisában és májusában kérdőíves adatfelvételt végeztünk a temerini „Lukijan Mušicki” középiskola magyar és szerb diákjai körében. Arra voltunk kíváncsiak, hogy a különböző helyek és terek, amelyekben a fiatalok élnek, amelyek körülveszik őket, s ezen belül elsősorban a lakóhelyük, Temerin milyen módon alakítják identitásukat.

A mintába az első osztály (a magyarországi 9. osztály) magyar és szerb tagozata (10-10 diák), valamint a harmadik (11.) osztály magyar (30 diák) és a negyedik (12.) osztály szerb (30 diák) tagozata került, összesen 80 diákot kérdeztünk meg. ${ }^{1}$ Hat kérdőív értékelhetetlennek bizonyult, a feldolgozhatatlan kérdőivek magyar gyerekektől érkeztek, az érvényes kérdőívet kitöltők között 34 diák járt magyar, 40 szerb osztályba. A válaszoló diákok 76,4\%-a nemcsak Temerinben él, de itt is született, míg 6,9\%-uk a kilencvenes években, 5,6\%-uk az ezredforduló után telepedett le családjával a városban. (A nem itt született, de Temerinben lakó diákok 9,7\%-a nem közölte Temerinbe érkezése idejét.) A megkérdezett középiskolásoknak csupán 1,4\%-a nem helyi lakos és ingázik a környező településekről.

A kutatásra közvetlenül azután került sor, hogy a városban magyar és szerb fiatalok sorozatosan összeverekedtek. E konfliktus médiaeseménnyé vált, a hírek a fiatalok közötti agressziót etnikai/nemzeti konfliktusként interpretálták. A konfliktus kapcsán a nyilvánosságban felmerült egy sor kérdés a fiatalok társadalmi helyzetéről, az önmagukról és a „másikról” mint barátról vagy ellenségről alkotott képről, a békés együttélés lehetőségéről alkotott vízióikról. Kutatásunk során egy felbolydult, feszült légkörü iskolai környezetbe csöppentünk, ez a körülmény alapvetően befolyásolta a kutatás módszertanát. Mivel a verekedéseket követően újságírók sora járt az iskolában és a városban, a diákok könnyen e felfoko-
\end{abstract}

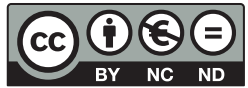


zott, az aktuális konfliktusoknak szóló kíváncsiságnak tulajdoníthatták volna megjelenésünket, nem tudtak volna elfogulatlan kutatóként elfogadni bennünket. Éppen ezért etikai megfontolásokból, attól tartva, hogy az amúgy is feszült hangulatban lévő diákokat kényelmetlen helyzetbe hoznánk, lemondtunk a személyes interjúk készítéséről. Ezt a módszertani hiányt azzal igyekeztünk valamelyest kiegyensúlyozni, hogy a kérdőívekben szereplő nyitott kérdésekkel lehetővé tettük számukra személyes véleményük kifejtését. A kérdőív tehát zárt és nyitott kérdéseket egyaránt tartalmazott. A nyitott kérdések által kínált lehetőséggel azonban többen nem éltek, és alig egy-két szavas válaszokat adtak. A választott módszertan lehetőséget adott arra, hogy az „identitás” kérdéskörét „vegyes”, kvantitatív és kvalitatív módon járjuk körbe, ugyanakkor le kellett mondanunk az identitás narratív dimenzióinak megismeréséről és megértéséről.

Kérdéseinkkel részint azt kívántuk feltárni, hogy Temerin, a hely, a közvetlen lakóhelyi környezet miként formálja, alakítja a diákok identitását. A kérdések egy csoportja a más (másik) etnikai csoportok értékeit, e csoportok tagjaival kialakított kapcsolatokat, az esetleges konfliktusokat firtatta. További kérdések pedig a diákok származási helyére, a nemzeti identitásra, valamint a megkérdezettek szempontjából - feltételezésünk szerint - fontos geopolitikai fogalmakra vonatkoztak.

\section{A tér és a hely (lakóhely) mint az identitás változói - elméleti megfontolások}

A hely és a tér alapvető elméleti jelentőséggel bírnak a különböző társadalmi csoportok, így a bevándorlók, az egyes etnikai csoportokhoz tartozók, a fiatalok, a kisebbségi közösségek, az állandó mozgásban lévő, vándorló csoportok identitásának kialakításában is. Másként fogalmazva, a térbeliség valamennyi társadalmi jelenség fontos dimenziója. A teret értelmezhetjük olyan kontextusként, amelyben a társadalmi élet zajlik, a tér ugyanakkor a társadalmi élet lenyomata is. Minden, az emberi léthez köthető tér tárgyakkal, alkotásokkal, társadalmi, kulturális folyamatokkal telített - ez a társadalmi (emberi) ökológiának, illetve a társadalmi terekkel foglalkozó elméletek többségének egyik alapvető feltevése (Strassoldo 1990, 20.).

A térben mindig érzékelhetők azok a megkülönböztetések és határok, amelyek a társadalmi életet is jellemzik (Sibley 1998, 86.). Castells nyomán azt mondhatjuk, hogy a tér a társadalmi szereplők szembenálló érdekei, értékei közötti konfliktusok és eltérő stratégiáik eredményeként jön létre (Castells 2000, 436.). Ebből következően a szociológiai elemzésekben a teret, a helyet nem lehet bizonyos társadalmi gyakorlatoktól függetlenül definiálni; a hely meghatározza azokat a társadalmi kapcsolatokat, amelyek a térnek formát, funkciót és társadalmi jelentést adnak (Castells 2000, 437.). 
Henri Lefebvre egyik legjelentősebb tézise a terekről mint társadalmi termékekről, a tér teremtéséről, termeléséről szól. Amennyiben a tér termék, azaz közvetíthető a társadalom által, akkor a térre vonatkozó tudásunk is tükrözi a tér teremtésének folyamatát (Lefebvre 1991). Lefebvre három teret különböztet meg. Az érzékelt tér (,,perceived space”) a hétköznapi térbeli gyakorlatok fizikálisan létező tere. Az elgondolt tér („conceived space”) a térrel kapcsolatos reprezentációkat jelenti: mindazokat a képzeteket, terveket, amelyeket a térről alkotunk (például térképek, fejlesztési tervek stb.). A harmadik tér a reprezentáció tere, amely „megélt tér” („lived space”): állandóan alakul, formálódik a tereket használók, elfoglalók, a „lakosok” és a „felhasználók” cselekedetei és reprezentációi, mentális folyamatai által. Lefebvre elképzelése szerint ez a három tér dialektikus kapcsolatban áll egymással, szerepük, jelentőségük a tér termelésében a különböző társadalmakban eltérően alakul. A reprezentáció tere, miközben szimbolikus karakterrel ruházza fel, el is fedi a fizikai teret. A teret használók, a társadalmi szereplők a konkrét térhez, adott térelemekhez különféle jelentéseket kötnek, amelyek révén adott terek az azokat használók számára helyekké válnak. A reprezentáció terei tehát (néhány kivételtől eltekintve) a többé-kevésbé koherens, szisztematikus nem verbális szimbólumok és jelentések irányába tolódnak el (Lefebvre 1991, 38-39.). Lefebvre koncepciójának ezen eleme a helyre mint olyan konkrét térre vonatkozik, amelyhez különböző jelentések tapadnak, amelyeket a társadalmi szereplők ,ismernek, birtokolnak”.

A társadalomtudományokban bekövetkezett ,térbeli fordulatnak” (spatial turn $)^{2}$ köszönhetően a társadalmi folyamatok kortárs elemzései elmozdultak a történelmi, időbeli megközelítések felől a térbeli (geográfiai) megközelítés felé (Soja 1989). A hely, tér és a mindennapi élet összefüggése úgy is értelmezhetö, hogy nemcsak az ember teremti a teret, hanem a tér is teremti az embert (Tuan 2001).

A tér megélésének módja szimbolikus, szociokulturális, valamint fizikai osztályozáson és minősítésen alapul. A terek mint materiális és fizikai entitások az őket létrehozó és állandóan újrateremtő társadalmi gyakorlatok által jönnek létre és formálódnak, teremtik meg azt, amit valóságnak érzékelünk (Benwell, Stokoe 2006, 211.). A valóság objektív/társadalmi és szubjektív/egyéni értelmezése között a reprezentációs terekben vagyunk, amelyek - ahogy Iver Nojman írja - olyan formában mutatják be a jelenségeket, amilyeneknek mi látjuk őket, vagyis a köztünk és a világ között lévő szűrőn keresztül (Nojman 2009, 42.).

Az egyének térre vonatkozó élményeiben és értelmezéseiben megjelenő reprezentációknak ${ }^{3}$ köszönhetően teljes értelmet és jelentőséget nyer az Henri Lefebvre által javasolt megkülönböztetés a tér reprezentációja - mint elgondolt és megtermelt tér -, valamint a reprezentáció tere - mint a képeken és szimbólumokon keresztül megélt tér - között. A társadalmi szereplők ruházzák fel a tereket értelemmel, jelentőséggel, és ezért a terekre vonatkozó kutatások egyik legfontosabb kérdése, hogy a szereplők mindennapi aktivitásuk során miként értelmezik azokat (Carlin 2003).

A közösségekről alkotott elgondolások és képzetek gyakran kötődnek a hely fogalmához. A közösségekhez azok a személyek tartoznak, akiknek vannak 
bizonyos közös érdekei, akiket közeli kapcsolatok és intenzív kommunikáció köt egymáshoz. A helyek nem jelentenek szükségszerüen közösségeket, habár elősegíthetik a közösségek kialakulását (Castells, 2000, 449-450.). Korábban széles körben élt az elképzelés, hogy a térbeli közelség jelentősen befolyásolja az interakciós folyamatokat (Pušić, 1997, 297.). Újabb kutatások azonban világossá tették, hogy a társadalmi kapcsolatok homogenitása nem függ közvetlenül a területi közelségtől, jóval inkább magyarázható etnikai, gazdasági, politikai és más jellegü tényezőkkel.

\section{A kérdőíves kutatás néhány eredménye}

\section{Földrajzi kötődés, identitás}

Abból a feltételezésből indultunk ki, hogy miközben a térhez, a helyhez (lakóhely) való kötődés meghatározó az identitás kialakulásában, annak jelentése szituatív és kontextustól függ. Azt vártuk tehát, hogy a kérdések megfogalmazásától, illetve a kérdésekben megjelenő fogalmak jelentésén, a hozzájuk tapadó érzelmi többleteken múlik, hogy a diákoktól milyen válaszokat kapunk. A következőkben e különböző módon megfogalmazott kérdésekre adott válaszokat elemezzük.

A diákok földrajzi környezetükhöz való kötődését zárt kérdéssel tudakoltuk, úgy, hogy a felkínált fogalmakat: „a szülőföld”, ,,a haza”, ,az ország”, ,a városom" a fontosságot jelző ötfokú skálán értékelhették. Arra is lehetőségük volt, hogy egyik felkínált területi fogalmat se értékeljék, ha az számukra semmit sem jelent vagy nem gondolkodnak róla. Tizenhat megkérdezett diák (a válaszadók 21,6\%-a) fejezte ki, hogy „nem gondolkodik” a feltett kérdésről, illetve hogy azt „nem tartja fontosnak”. A diákok 40,4\%-a számára a közvetlen környezetüket jelentő város, Temerin a „legfontosabb”, további 25\%-uk a „nagyon fontos” jelzőt kapcsolta a városhoz (1. ábra).

A városhoz való kötődésben nem tapasztalható lényeges különbség a tanulók nemzeti hovatartozása mentén. A szerb és magyar diákok egyaránt döntően a „legfontosabb” vagy a „nagyon fontos” jelzőt használták. A szerb diákok 43,8\%-a számára a „legfontosabb”, 18,8\%-a számára „nagyon fontos” a városa. A magyar diákok válaszai kiegyenlítettebb mintázatúak (a „legfontosabb” és a „nagyon fontos” egyaránt 35-35\%-kal jelenik meg), ugyanakkor összességében jelentősebb a városhoz való kötődésük (70\%-nak legfontosabb, illetve nagyon fontos), mint a szerb diákoké (akiknél ez az arány összesen 62,6\%).

A ,szülőföldhöz” a legtöbben a „fontos” jelzőt kötötték (34,9\%), a „legfontosabb" minősítést a megkérdezettek 27,9\%-a nevezte meg. A szerb diákok 22,2\%-a a „szülőföldet” a „legfontosabbnak” tartotta, ez az arány a magyar diákok körében jóval magasabb (37,5\%) volt. 
1. ábra: A szerb és magyar diákok földrajzi kötődései

Geographical affections of Serbian and Hungarian students

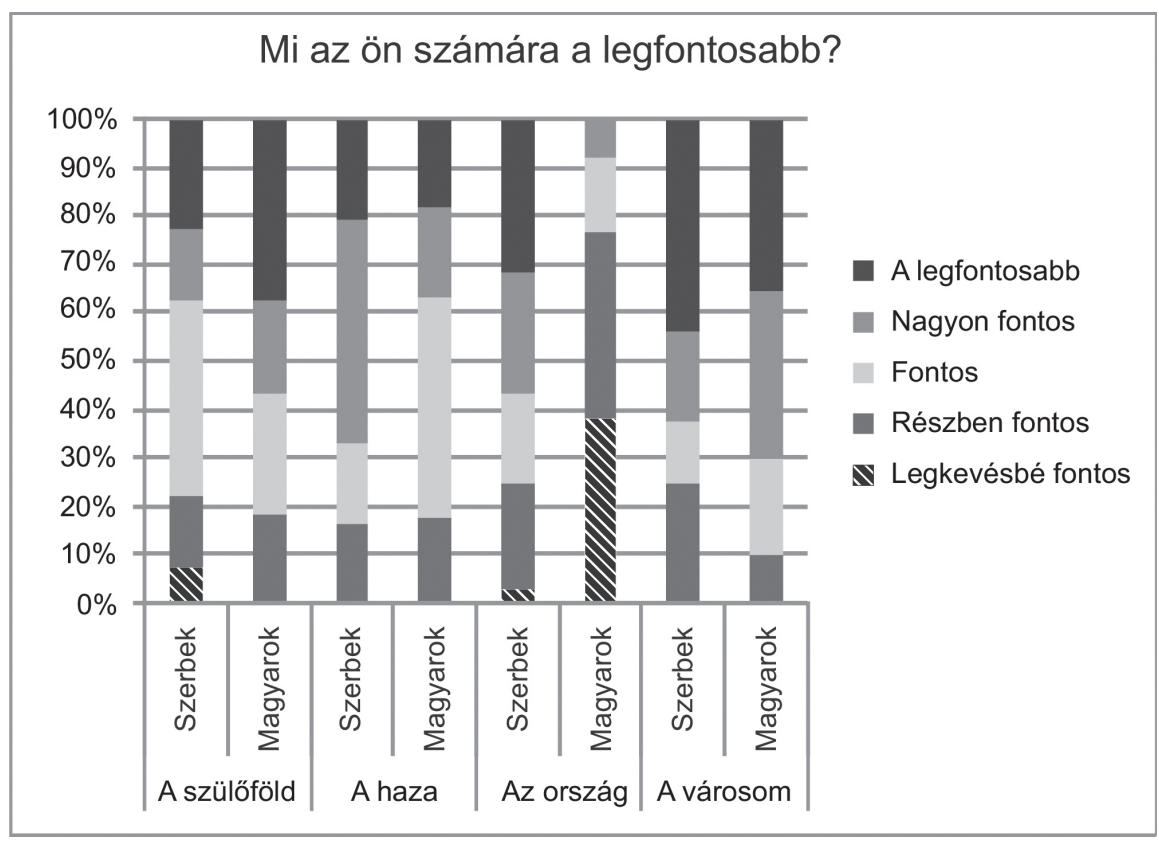

A nemzeti hovatartozás az „államhoz” való kötődés vonatkozásában eltérő válaszokat eredményezett (2. ábra). Általában a legtöbb válaszadó $(26,7 \%)$ „kevésbé fontosnak" tartja az államot, ugyanakkor 22,2\%-uk a „legfontosabb" jelzőt választotta. Míg a szerb diákok 31,3\%-a számára az állam a „legfontosabb” kategóriát jelenti, addig a magyar tanulók egyáltalán nem tartották a „legfontosabbnak” az államot, sőt a „nagyon fontos” jelzőt is csak a válaszadók 7,7\%-a használta. A „haza” szó az összes diák 37,1\%-a szerint „,nagyon fontos”, a válaszadóknak csupán 20\%-a használta a „legfontosabb” jelzőt. A nemzeti hovatartozás nem befolyásolta a válaszok megoszlását.

Meg kell jegyeznünk, hogy a 74 tanuló közül húszan (27\%-a) nem válaszoltak arra a kérdésre, hogy mit tekintenek hazájuknak, szülőföldjüknek. A legtöbben (41,7\%) Szerbiát jelölték meg hazájukként/szülőföldjükként, ám Temerint is többen (35,2\%), míg a „Vajdaságot” a diákok 11\%-a tekinti szülőföldjének. A szerb osztályba járó tanulók Szerbiát és Temerint egyforma arányban (44,4\%) tekintik szülőföldjüknek/hazájuknak. A magyar diákok legnagyobb arányban ugyancsak Szerbiát nevezik meg hazájuknak/szülőföldjüknek (37,9\%), ugyanakkor Temerint csak 27,6\%-uk jelölte meg. A magyar diákok egyötöde a Vajdaságot (20,7\%), 13,8\%-uk Magyarországot nevezte hazájának/szülőföldjének.

Arra is megkértük a diákokat, hogy indokolják válaszaikat. A Temerint szülőföldjükként megjelölők válaszaiból idézünk néhány példát. „Az a hely, ahol születtem és felnőttem, itt az életem...” (1. osztályos szerb diáklány). „Az a hely ahol 
2. ábra: Kötődés a hazához, szülőföldhöz Affection for home, homeland

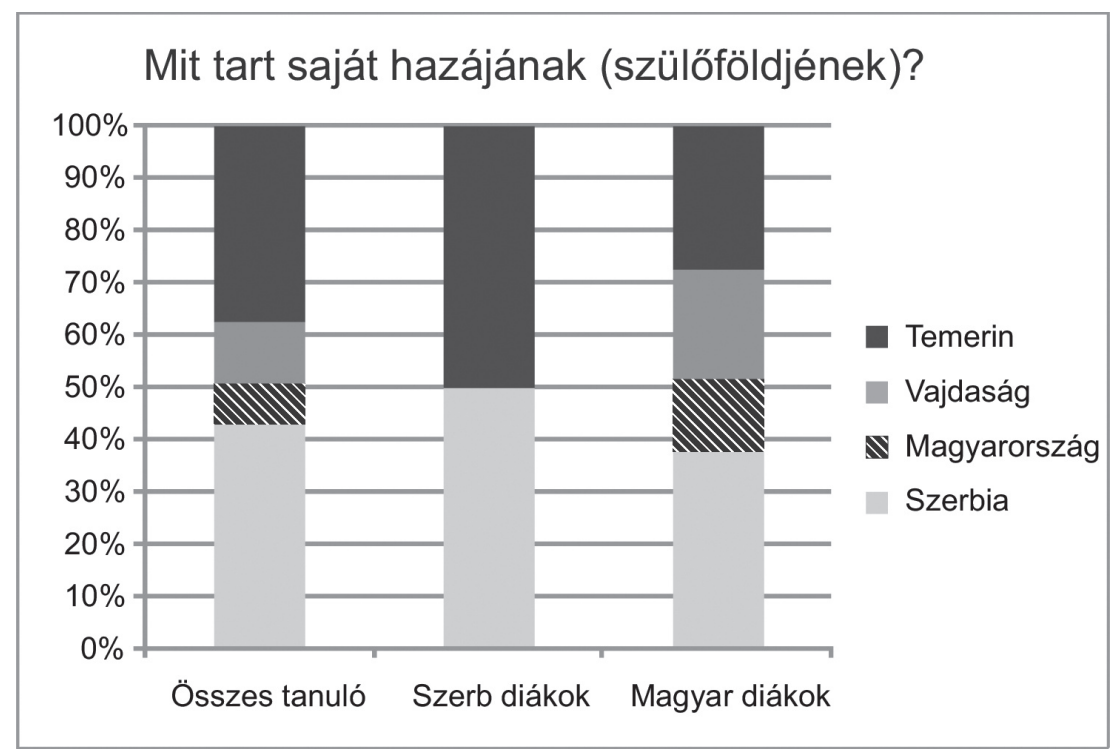

születtem, ahol azok a személyek vannak, akiket legjobban szeretek" (1. osztályos szerb diáklány). „Azért Temerin, mert itt születtem és itt van a legszükebb rokonságom” (4. osztályos szerb diáklány). „Ahol élek és ahol születtem” (1. osztályos magyar diáklány). „Szülőhely, mert itt születtem és itt élek” (1. osztályos magyar diáklány). „Temerin, mert itt élek” (3. osztályos magyar diáklány). Sem a magyar, sem a szerb diákok nem adtak másféle válaszokat akkor, ha nem Temerint, hanem Szerbiát vagy a Vajdaságot nevezték hazájuknak/szülőföldjüknek; azzal magyarázták válaszukat, hogy itt élnek, itt születtek, itt él a rokonságuk, itt vannak a barátaik stb. Előzetesen azt feltételeztük, hogy a diákok kötődése a városhoz, Temerinhez erősebb, mint az elvontabb földrajzi és szimbolikus térfogalmakhoz. Az eredmények azonban nem igazolták várakozásunkat.

A diákoknak feltettük azt a zárt kérdést is, hogy legszívesebben hogyan jellemeznék magukat: európaiként, kelet-európaiként, szerbként vagy magyarként, esetleg temerininek, vajdaságinak tekintik magukat (3. ábra). Választhatták továbbá a „valami más” kategóriát is. Ahogy az előző kérdések esetében, úgy ezúttal is módjuk nyílt arra, hogy a felkínált lehetőségeket ötfokú skálán értékeljék (1: legfontosabb - 5: legkevésbé fontos).

Az összes válaszoló közel ötöde (19,7\%) tartotta a „legfontosabbnak”, 44,3\% pedig „nagyon fontosnak” azt, hogy temerini. A szerb anyanyelvű diákok 3,1\%-a tartotta „legfontosabbnak”, és 51,6\%-a „,nagyon fontosnak” temerini mivoltát, elsöprö többségük azonban szerbnek tartja magát, s ehhez 92,1\%-uk a „legfontosabb" jelzőt kapcsolta. A magyar anyanyelvü diákok is magas, de a szerb tanulóknál lényegesen kisebb arányban jellemezték nemzeti hovatartozásukat 
3. ábra: A szerb és magyar diákok identitása

Identity of Serbian and Hungarian students

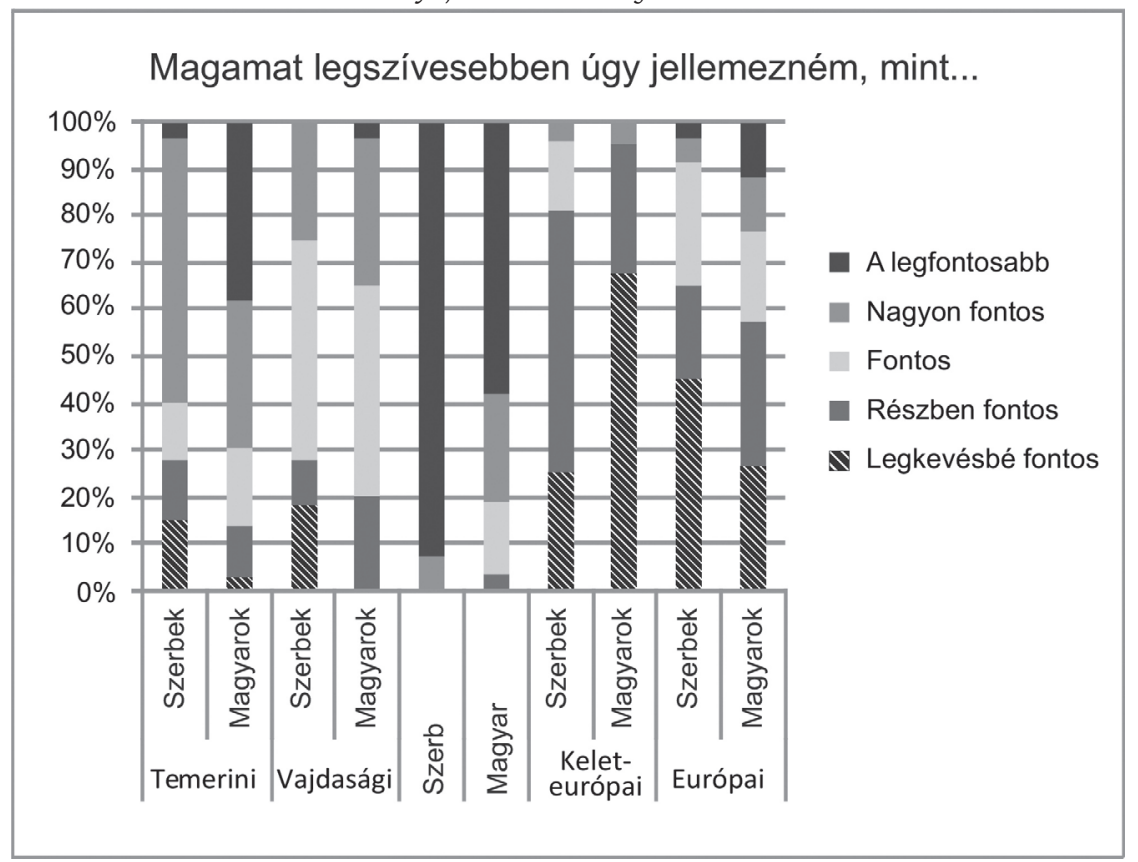

mint a „legfontosabb” (57,7\%), vagy „nagyon fontos” tulajdonságukat (23,1\%), míg Temerinhez 37,9\%-uk kötötte a „legfontosabb”, 31\% pedig a „,nagyon fontos” jelzőt. Jól látható tehát, hogy a diákok szemében az etnikai közösséghez tartozás jóval fontosabb, mint az egyéb, etnikailag vegyes közösségekhez (régió, település) való kötödés. Az olyan fogalmak pedig, mint Európa vagy Kelet-Európa nehezen megfoghatók egy tinédzser számára, aki nem biztos, hogy járt a tágabb régión kívül. ${ }^{4}$

Arra, a kérdésre, hogy miért tartják fontosnak nemzeti hovatartozásukat, a válaszokat néhány példával illusztráljuk.

„Azért, mert magyar vagyok és Vajdaságban élek" (1. osztályos magyar diáklány). „Magyar vagyok és vajdasági, és mert itt születtem” (3. osztályos magyar diáklány). „Mert itt nőttem fel Temerinben” (3. osztályos magyar diák). „Azért jellemeztem magam így, mert szeretem Szerbiát, és itt születtem” (1. osztályos szerb diák). „Szerb vagyok, és ez a legfontosabb” (4. osztályos szerb diák). „Ez jelzi, hogy népemhez tartozom" (4. osztályos szerb diáklány).

Kutatási eredményeink alapján úgy tűnik, hogy a diákok számára nemzeti hovatartozásuk, identitásuk fontosabb, mint az őket a szülőföldjükhöz, lakóhelyükhöz, Temerinhez füző kötelékek, ám míg a szerb diákok számára a nemzeti identitás tűnik a legfontosabbnak, addig a magyar diákok esetében a lokális kötődés és a nemzeti hovatartozás kiegyesúlyozottabb arányáról beszélhetünk.

A kutatás módszertana és eredményei alapján nem tudjuk megmondani, hogy a megkérdezett diákok Temerinhez, Szerbiához, Magyarországhoz való 
kötődése mennyire mély, intenzív. Az viszont véleményünk szerint kiderült az adatokból, hogy Temerin, a lokalitás fontos szerepet tölt be a magyar és szerb diákok identitásában.

\section{Kapcsolatok és attitüdök a „másikkal” szemben}

A megkérdezett diákok „nemzeti kötődéséről” kibontakozó képet tovább árnyalhatják azok az eredmények, amelyek a magyar és szerb gyerekek más nemzetiségekkel ápolt kapcsolataira, más etnikai csoportokhoz füződő viszonyaira vonatkoznak. Ezekben az esetekben is több válaszlehetőséget kínáltunk föl.

Az első kérdés így hangzott: „Vannak-e más nemzetiségü barátaid?” Összességében a gyerekek valamivel több mint harmada válaszolt nemmel. Ugyanakkor 30\%-uk nyilatkozott úgy, hogy kisgyermek kora óta vannak más nemzetiségű barátai, további $20 \%$-uk pedig régóta barátkozik más nemzetiségüekkel. Mindössze a diákok 3\%-a írta azt a kérdésre, hogy nem is akarna olyan fiatalokkal barátkozni, akik nem a saját nemzetiségéhez tartoznak.

Az átlagok mögött azonban jelentős, etnikai törésvonalra utaló különbségek húzódnak. A szerb diákoknak ugyanis éppen a fele válaszolt nemmel erre a kérdésre, ők tehát saját bevallásuk szerint csak a saját nemzetiségükön belül kötnek barátságokat. Ezzel szemben a szerb diákok másik felének van más nemzetiségű barátja; 22\%-nak már gyermekkora óta. Mindössze 2\% nyilatkozott úgy, hogy most nincs, de korábban volt ilyen barátja, 5\%-uk jelentette ki, hogy nem is szeretne más nemzetiségü fiatalokkal barátkozni. A magyar diákok válaszai egészen eltérő mintázatúak. Mindösszesen a gyerekek 17\%-a írta a kérdésre, hogy nincsenek más nemzetiségü barátai, ezzel szemben több mint 80\%-uknak van(nak), és 38\%-uk már kora gyerekkora óta ápol ilyen barátságokat. Csupán 3\%-uk írta, hogy korábban volt, de ma már nincs más nemzetiségü barátja, illetve nem is óhajt velük barátságot kötni.

Azt is megkérdeztük a fiataloktól, hogy szeretnének-e más nemzetiségű fiúval/lánnyal járni, szívesen vennék-e, ha szomszédjuk, barátjuk, ismerősük, iskolai tanáruk egy másik nemzetiséghez tartozna. ${ }^{6}$ Általában azt mondhatjuk, hogy az igen válaszok meghatározóak, kivéve a más nemzetiségű szomszédot, ${ }^{7}$ tanárt és partnert, vagyis a legközvetlenebb, leginkább bensőséges, gyakori érintkezésen alapuló és - a partnerek esetében - intim kapcsolatokat tudják a legkevésbé elképzelni más nemzetiségű emberekkel. Az összes tanuló 43\%-a jelezte, hogy nem kívánna magának olyan partnert, aki nem a saját nemzetiségéhez tartozik, ezzel szemben csak $2 \%$ tudta magát vegyes kapcsolatban elképzelni. E válaszok értékelésekor érdemes megfontolnunk, hogy a vegyes házasságok esélyeit - az egyéni választásokat figyelmen kívül hagyva - csökkentik a nyelvi, vallási, kulturális, mentalitásbeli különbségek. Kisebbségi magyar nézőpontból pedig a vegyes házasság a kisebbségi közösség gyengülését eredményezi - lásd ehhez Váradi (2013) tanulmányát e számban. ${ }^{8}$ 
1. táblázat: Elfogadna-e más nemzetiségűt ...?

Would you accept a member of another nationality as...?

\begin{tabular}{|c|c|c|c|c|c|c|}
\hline & & $\begin{array}{c}\text { Barátnak/barátnőnek } \\
\text { (partnerként) }\end{array}$ & Szomszédnak & Barátnak & Ismerösnek & $\begin{array}{c}\text { Iskolai } \\
\text { tanárnak }\end{array}$ \\
\hline \multirow[t]{3}{*}{ Szerb diákok } & igen & 18,4 & 20,5 & 31,6 & 31,6 & 18,4 \\
\hline & nem & 55,3 & 28,2 & 26,3 & 23,7 & 26,3 \\
\hline & nem érdekli & 26,3 & 51,3 & 42,1 & 44,7 & 55,3 \\
\hline \multirow[t]{3}{*}{ Magyar diákok } & igen & 34,4 & 25 & 43,8 & 46,9 & 15,6 \\
\hline & nem & 28,1 & 18,8 & 15,6 & 18,8 & 31,3 \\
\hline & nem érdekli & 37,5 & 56,3 & 40,6 & 34,4 & 53,1 \\
\hline
\end{tabular}

A más nemzetiségű szomszéd vonatkozásában 22,5\% mutatkozott elfogadónak, míg 23,9\% elutasítónak. A barátok esetében már többen (37\%) mutatkoztak nyitottnak, míg 21,5\% nem akart más nemzetiségü barátot elfogadni - ez az arány jóval magasabb, mint az előző, a létező baráti kapcsolatokat firtató kérdés esetében, és erőteljesebb elutasításra, a saját csoportba való bezárkózás nagyobb hajlandóságára utal. A más nemzetiségű ismerősök esetében hasonló arányszámokat láthatunk: 38,6\% elfogadna, míg 21,4\% elutasítana „vegyes” társaságot.

Ezzel szemben más nemzetiséghez tartozó tanárt mindössze a válaszoló diákok 17,1\%-a tartana elfogadhatónak, míg 28,6\%-uk nem látna szívesen ilyen pedagógust.

Ha a válaszokat a diákok nemzetiségi hovatartozása, kötődése mentén vesszük szemügyre (1. táblázat), azt mondhatjuk, hogy a szerb diákok leginkább a más nemzetiségü barátok és ismerősök felé nyitottak, őket fogadnák el a legnagyobb arányban, ezzel szemben a magyar tanulók minden felkínált kategória esetében nagyobb arányban adtak igenlö, mint nemleges válaszokat - kivételt a más nemzetiségü tanár jelent, akit kevésbé látnának szívesen. Ez azzal magyarázható, hogy a diákok szívesebben tanulnak az anyanyelvükön - éppen azért léteznek a párhuzamos szerb és magyar osztályok, hogy az anyanyelvi oktatást biztosítsák a kisebbségi gyerekek számára is. Összességében az a kép bontakozik ki előttünk, hogy - legalábbis az attitüdöket illetően - a magyar diákok nyitottabbak, elfogadóbbak a más nemzetiségűekkel szemben, mint szerb társaik.

\section{Néhány tanulság}

Kutatásunk során nem törekedtünk arra, hogy „a temerini fiatalok identitását” kvantitatív módon feltárjuk, elemezzük. Csupán néhány tendencia azonosítására vállalkoztunk. Vajon a fiatalok hajlamosak-e a nemzetükkel való azonosulásra, s ha igen, milyen módon? Hogyan gondolkodnak az olyan fogalmakról, mint állam, Európa, nemzet vagy Vajdaság? Éppen ez volt az oka annak, hogy kötődéseikre többféle módon kérdeztünk, semlegesebb és érzelmileg telítettebb fo- 
galmak, földrajzi nevek alkalmazásával, mint ország, haza, város, illetve Szerbia, Magyarország, Vajdaság vagy Európa.

A tér, a hely perdöntő szerepet játszik az identitások kialakulásában, az identitáskonstrukciók azonban szituatívak és kontextusfüggők. Beigazolódott az a kiinduló feltételezésünk, hogy a diákok a megfogalmazástól függően adnak választ az identitásukat, a helyekhez való kötődésüket firtató kérdésekre. Mindez a kutatásunkra lefordítva azt jelenti, hogy a kérdések megfogalmazásától függően eltérő válaszokat és értelmezéseket kaptunk. Amikor a térbeli egységekről elvontabb, politikailag semlegesebb kategóriákban fogalmaztunk (város, állam, régió stb.), a diákok másként válaszoltak, mint amikor politikai és érzelmi jelentéssel átitatott földrajzi neveket (Temerin, Vajdaság, Szerbia) használtunk. Az eredmények nem igazolták azt a várakozásunkat, hogy a diákok jobban kötődnek a lokalitáshoz, Temerinhez, mint az absztraktabbnak tekinthető földrajzi, politikai entitásokhoz (mint Vajdaság, Szerbia, Magyarország, Kelet-Európa, Európa).

Úgy is fogalmazhatunk, hogy kutatásunk ugyan rávilágított a lokalitásnak a fiatalok identitáskonstrukcióiban játszott jelentőségére, ugyanakkor arra is rámutatott, hogy a megkérdezett diákokat a lokalitáshoz nem füzik erősebb kötelékek, mint saját etnikai csoportjukhoz, illetve nemzetükhöz. Lokális identitásuk tehát nem erősebb, mint nemzeti, etnikai identitásuk. Ez az eredmény talán nem is meglepő egy olyan vegyes etnikai összetételü településen, ahol a szerb-magyar együttélésre éppen a fiatalabb generációk esetében fel-feltörő, nyílt konfliktusok vetnek árnyékot.

Érdemes felhívni a figyelmet egy köztes szint, a vajdasági regionális identitás megjelenésére. A megkérdezett magyar tanulók 20,7\%-a jelölte meg a Vajdaságot mint szülőföldjét/hazáját, míg ez a szerb diákoknál elenyésző volt. A regionális identitás megléte a felnőtt magyar lakosság körében még jelentősebb: több mint felük a Vajdaságot tartja szülőföldjének vagy hazájának. ${ }^{9}$ Mindezt leginkább azzal magyarázhatjuk, hogy a kisebbségi „paradoxon” (azaz szerb állampolgárok, de magyar nemzetiségúek) következtében a Vajdaság az a közös halmaz, amelybe mind a szerb állampolgári lét, mind a magyar nemzethez való tartozás (amelynek történeti területi kerete magába foglalta a Vajdaságot) belefér. A magyar közösségen belül a vajdasági vagy délvidéki magyar kategória a legáltalánosabban használt önmeghatározás. A mai Szerbiából származó magyarok szívesebben használják a Vajdaság kategóriát, amihez olyan képzetek társulnak, mint multikulturális, soknemzetiségű világ, amelyben lehetőség nyílik az egymástól való tanulásra - lásd ehhez Váradi, Erőss (2013) tanulmányát e számban. E pozitív képzet teszi vonzóvá a Vajdaság mint szülőföld, haza kategóriáját a magyarok számára. ${ }^{10}$ Ezzel szemben a szerb lakosság számára - fóként a délszláv polgárháború után - a (központosított) szerb nemzetállamhoz, illetve a szerb nemzethez való tartozás értékelődött fel, ráadásul a boszniai, horvátországi, koszovói menekültek körében aligha alakulhatott ki tizenöt-húsz év alatt valamilyen vajdasági identitás - lásd ehhez Ristić, Nagy, Kicošev (2013) írását e számban. 
Arra vonatkozóan, hogy a fiatalok ápolnak-e barátságot más nemzetiségű kortársaikkal, illetve milyen attitűddel viseltetnek más nemzetiségű emberekkel szemben, a diákok válaszai arra mutatnak rá, hogy gyakoriak a különböző nemzetiségi csoportok közötti barátságok, és az attitűdök szintjén láthatóan nem kevesen vannak a másokkal szemben nyitott, elfogadó gyerekek is. Ugyanakkor úgy tünik, mintha a szerb fiatalok elzárkózóbbak lennének a más nemzetiségűektől, mint a magyarok. Csak feltételezhetjük, hogy e különbségek mögött a magyar fiatalok esetében a kisebbségi léthelyzet, illetve a temerini többnemzetiségű világ magától értetődő tapasztalata húzódik, míg a szerb diákok esetében a nemzeti szinten többségi, domináns helyzetből fakadó „kényelem”.

\section{Jegyzetek}

1 A temerini „Lukijan Mušicki” technikumban fémmegmunkáló, fodrász, textil és közgazdasági szakon folyik képzés. A 2011/2012-es tanév elején beiratkozott 384 diák közül 268 tanul szerb, 116 tanuló pedig magyar nyelven. Az első osztály 63 diákja közül 32 tanul magyar nyelven, a második osztály 75 tanulója közül 18, a harmadik osztály 95 tanulója közül pedig 43. A negyedik osztályosok (végzősök) közül több a magyar anyanyelven tanuló diák, harmincötből 23. A szerb és magyar diákok közösen szerkesztik az iskola lapját (Generacija/Korosztály), évente több közös előadást szerveznek (gyermekhét, újév, évzáró). Nagyobb számú diák készül a Szent Száva-ünnep alkalmából rendezett előadásra és író-olvasó találkozóra is. A magyar és szerb diákok együtt versenyeznek az évente kétszer megrendezett sportnapon (kézilabda, foci, női „szuperrúgás”) és együtt rendezik, tartják tisztán az iskola környékét. Az iskolán kívül azonban nem jellemző, hogy a magyar és szerb diákok közösen töltenék az idejüket. (Az információk a középiskola igazgatójától származnak.)

2 A társadalomtudományokban végbement térbeli fordulat szakítást jelent azokkal a hagyományos megközelítésekkel, amelyekben a tér és a társadalom különálló, de egymással összefüggésben lévő fogalmak.

3 Andrea Jansson elképzelése szerint a földrajz és a kommunikáció közti kapcsolat az alábbi tényekben tükröződik: a) a reprezentáció minden formája térben jelenik meg; b) minden tér a reprezentáció által jön létre (Jansson 2005).

4 A fenti fontossági sorrend a felnőtt magyar lakosság körében sem tér el számottevően, bár jóval nagyobb azok aránya (24\%), akik önmagukat elsősorban vajdaságiként definiálják (Gábrity Molnár, Rác 2007, 126.).

5 A válaszlehetőségek a következők voltak: 1. igen, már gyerekkorom óta; 2. igen, már hosszabb ideje; 3. igen, az utóbbi időben; 4. most nincsenek, de voltak; 5. nincsenek; 6. nincsenek, és nem is akarom, hogy legyenek. A szövegben csak a leggyakoribb válaszokat mutatjuk be, amelyek a diákoknak a „másik” nemzetiséggel való viszonyát legjobban érzékeltetik.

6 Ennél a kérdésnél három válaszlehetőség volt: 1. igen; 2. nem; 3. nem foglalkoztat a kérdés.

7 A szomszédságról, a szomszédokkal való rendszeres kávézás szokásáról lásd pl. Váradi (2013) tanulmányát e tematikus számban.

8 Különböző tanulmányok a vegyes házasságokat a ,jugoszláv” identitás megnyilvánulásának tekintették, ám néhány demográfus amellett érvel, hogy még a leginkább multikulturális Bosznia-Hercegovina esetében is túloztak a vegyes házasságok számára és jelentőségére vonatkozó számítások, becslések (lásd ehhez Burić 2010, 228-229.).

9 A 2007-es Kárpát panel szerint a vajdasági magyarok kétharmada tekinti szülőföldjének a Vajdaságot, míg a települést, ahol született vagy él, mindössze 19\%. Ennél is kevesebben tekintettek szülőföldjüknek valamilyen államalakulatot: Szerbiát (7,4\%), illetve a jelenlegi vagy 
történeti Magyarországot (3,5\%). E kutatás elkülönítette egymástól a szülőföld és a haza fogalmát. Arra a kérdésre, hogy mit tekint hazájának, a vajdasági magyarok 55\%-a válaszolta, hogy a Vajdaságot, míg a települési szint (ahol él vagy ahol született) a válaszok 11\%-át tette ki. Ugyanakkor erősen megnövekedett az államalakulatok szerepe, hiszen Szerbiát a válaszadók 24\%-a tekintette hazájának, a történeti vagy jelenlegi Magyarországot pedig 5,3\% (Gábrity Molnár, Rác 2007, 128.).

10 A vajdasági identitás egyre inkább megjelenik a népszámlálások adataiban is. Az elmúlt három népszámlálás során $(1991,2002,2011)$ egyre több vajdasági deklarált regionális kötődést a nemzetiséget firtató kérdésre (1991: 2 503, 2002: 10 154, 2011: 28567 fö). Ezzel párhuzamosan a magukat jugoszláv nemzetiségűnek vallók száma drasztikusan csökkent (1991: 174 ezer, 2002: 50 ezer, 2011: 12 ezer), így feltételezhetjük, hogy az etnikailag semleges jugoszláv kategória szerepét egyre inkább a regionális (vajdasági) kötődés kategóriája váltja fel.

\section{Irodalom}

Benwell, B., Stokoe, E. (2006): Discourse and identity. Edinburgh University Press, Edinburgh

Burić, F. (2010): Dwelling on the ruins of Socialist Yugoslavia: Being Bosnian by remembering Tito. In: Todorova, M., Gille, Zs. (eds.): Post-communist nostalgia. Berghahn Books, New York, Oxford, 227-243.

Carlin, A. (2003): Observation and membership categorization: Recognizing "normal appearances" in public space. Journal of Mundane Behavior, 1., 77-91.

Castells, M. (2000): Uspon umreženog društva. Golden Marketing, Zagreb

Gábrity Molnár I., Rác L. (2007): Kárpát Panel - Vajdaság. Gyorsjelentés. In: Papp Z. A., Veres V. (szerk.): Kárpát Panel 2007. MTA ENKI, Budapest, 120-184.

Jansson, A. (2005): For a geography of communication. Linköping Electronic Conference Proceedings, 015. http://www.ep.liu.se/ecp/015/ (Letöltés: 2011. július 30.)

Lefebvre, H. (1991): The production of space. Blackwell, Oxford, Cambridge

Nojman, I. B. (2009): Značenje, materijalnost, moć: Uvod u analizu diskursa. Centar za civilno-vojne odnose, Alexandria Press, Beograd

Pušić, Lj. (1997): Grad, društvo, prostor - sociologija grada. Zavod za udžbenike i nastavna sredstva, Beograd

Ristić, D., Nagy I., Kicošev, S. (2013): Szerb menekültek Temerinben: identitás és integráció. Tér és Társadalom, 2.,

Sibley, D. (1998): Geographies of exclusion. Society and difference in the West. Routledge, London, New York

Soja, E. W. (1989): Postmodern geographies. The reassertion of space in critical social theory. Verso, London, New York

Strassoldo, R. (1990): The social construction and sociological analysis of space. In: Hamm, B., Jalowiecki, B. (eds.): The social nature of space. Polish Academy of Sciences, Committee for Space Economy and Regional Planning, Warszawa, 19-49.

Tuan, Y. F. (2001): Space and place. The perspective of experience. University of Minnesota Press, Minnesota

Váradi M. M. (2013): Migrációs történetek, döntések és narratív identitás. A tanulmányi célú migrációról - másként. Tér és Társadalom, 2., 96-117.

Váradi M. M., Erőss Á. (2013): „Kulturálisan vagyunk magyarok, mentalitásban szerbek vagyunk szerintem, igen." Magyarországon élő vajdasági magyar migránsok és a jugóbuli. Tér és Társadalom, 2., 55-76. 